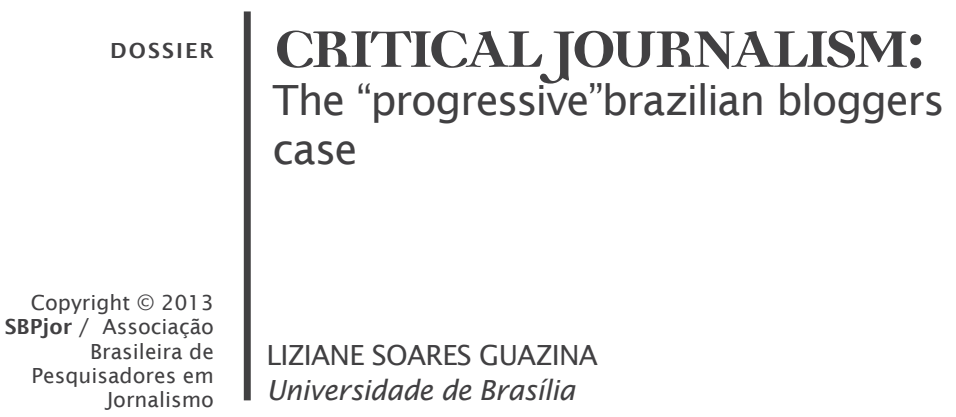

\begin{abstract}
This paper aims at understanding what comprises the professional identity of a well-known group of experienced Brazilian journalists who, at the same time, express their political opinion in independent blogs and define themselves as "progressive" or "dirty". Our objective is to understand how these bloggers define and practice journalism in their blogs and how they view their work in a democratic context. Through various interviews, we mapped out their main journalistic values and described their professional identity as blogger journalists who advocate critical journalism, in other words, opinionated journalism. The results showed that these journalists consider their blogs to be a place for a wide range of opinions against traditional media, and that their main job as online journalists is to be vigilant in relation to political powers, including the media which is seen as an important and relevant political actor in Brazil.
\end{abstract}

Keywords: Political journalism. Professional identity. Blogs. "Progressive" bloggers. Internet.

\title{
JORNALISMO QUE TEM LADO: o caso dos blogueiros brasileiros "progressistas"
}

RESUMO - Neste artigo, analisamos como se constitui a identidade profissional de um grupo de jornalistas experientes e atuantes no mercado, que, ao mesmo tempo, assinam blogs independentes para expressar sua opinião política e se assumem publicamente como "progressistas" ou "sujos". Nosso objetivo é compreender como esses blogueiros definem e praticam o jornalismo em seus blogs, e como entendem sua própria atuação no contexto democrático. A partir de entrevistas, mapeamos os principais valores jornalísticos expressos por eles, delineando sua identidade profissional de jornalistasblogueiros que praticam um jornalismo "que tem lado", isto é, de opinião. Os resultados mostram que esses jornalistas consideram seus blogs lugar de diversidade de opinião em oposição à mídia tradicional, e que sua principal função, enquanto jornalistas, é atuar de maneira vigilante em relação aos poderes políticos, incluindo a mídia, vista como ator político relevante.

Palavras-chave: Jornalismo político. Identidade profissional. Blogs. Blogueiros "progressistas". Internet. 


\title{
PERIODISMO QUE TIENE BANDO: el caso de los blogueros brasileños "progresistas"
}

\begin{abstract}
RESUMEN - En este artículo analizamos la forma en que se constituye la identidad profesional de un grupo de periodistas experimentados y activos en el mercado brasileño, que, al mismo tiempo, firman blogs independientes para expresar su opinión política y se declaran públicamente como "progresistas" o "sucios" (en referencia al insulto que les lanzó el candidato Serra). Nuestro objetivo es comprender cómo definen y practican el periodismo en sus blogs y cómo entienden su propia actividad en el contexto democrático. A partir de entrevistas, pretendemos describir los principales valores periodísticos que perfilan su identidad profesional como periodistas-blogueros que practican un tipo de periodismo "que tiene bando", es decir, de opinión. Los resultados muestran que estos periodistas perciben sus blogs como un lugar de expresión de diversidad de opinión, en oposición a los medios de comunicación tradicionales, y que su principal función, como periodistas, es actuar de manera vigilante con relación a los poderes políticos, incluyendo los medios, considerados por ellos como un actor político relevante e integrante del poder.

Palabras clave: Periodismo político. Identidad profesional. Blogs. Blogueros "progresistas". Internet.
\end{abstract}

\section{INTRODUCTION}

In the dispute to win the hearts and minds on the Internet, political journalism has increasingly catalyzed Brazilian political life and organized different social groups towards main national political events. Despite all the problems arising from structural changes journalism has gone through in terms of its production / distribution throughout the world, journalists continue to play an active role in and out of cyber public space. Political journalism still feeds much of the political process, whether through criticism, complaints, or affiliation to different governments, political parties, movements and / or political groups. ${ }^{2}$

When investigating how online political journalism happens in a journalist's personal blog (Adghirini and Pereira, 2006), it is possible to get a better understanding of the actual workings of journalism and of contemporary liberal democracies, especially since the year 2000 with the increase of internet access and resulting growth of online $e^{3}$ public participation.

Schudson (2009) points out that in the United States, blogs and bloggers have been recognized as a political force since $2002^{4}$. In Brazil, blogs linked to political parties, politicians or political journalists became more visible after the political crisis of 2005 (known as the Mensalão scandal) (Aldé, Escobar and Chagas, 2007). ${ }^{5}$ 
As Aldé and Chagas (2005) point out, amid the abundance of news and information on political events available online, well-known journalists' blogs still serve as guides for the millions of internet users who browse and participate in political debates, sharing their comments, criticisms and opinions. ${ }^{6}$ According to Aldé and Chagas, such journalists play the role of "organizers authorized by journalism credibility" to publish information online. Due to this credibility (often achieved outside the web), they act as references indicating what to read and what to interact with; legitimizing political beliefs, attitudes, or sources.

Moreover, online journalism uses technological advances made available through network communication, favoring real time news, interaction, and also the ability to manifest itself visible in a free and personal way. ${ }^{7}$

Canavilhas (2003) sets forth several characteristics related to online journalistic language and news making. One of these characteristics, according to the author, is precisely that "in web journalism, news should be seen as the beginning of something, and not an end in itself. It should "trigger" discussions with readers" (Canavilhas, 2003, p. 69).

According to the author, Internet news has the potential to be rewritten and reproduced several times and in various formats within the events dynamic and the permanent relationship between journalists and politicians, incorporating their feedback in real time. In this sense, the news works as drafts; something that can be modified according to the instant interactions and repercussions.

The new possibilities of such network have changed the dynamics of production routines and challenged the very constitution of the profession, making journalists work in an environment of strong structural changes (Adghirni and Pereira, 2011). Additionally, this leads professionals to develop different ways of building their professional identity, emphasizing blogs as a space for producing journalism and also to the opposition between technical and intellectual activities, especially in blogging, as shown by the authors in the previous text (Adghirni and Pereira, 2006).

Thus, sources, journalists, and the public are all producers of information which can be framed and contextualized, given new meaning, criticized, or supported by different social actors, providing for a more public and horizontal debate, highly prone to force social changes in a local and / or global scale. ${ }^{8}$ The debates are no longer led only by traditional social actors (politicians, journalists, intellectuals, 
government, political parties, social movements), but by other groups, movements or individuals that make their interpretations of the facts and testimonies public.

Therefore, they try to intervene in political conflicts, as the Internet has reduced the cost of producing and publishing technical information in multiple formats (videos, podcasts, texts, etc.) (Mastrini, 2012). According to Aldé and Chagas (2005), this transformation tends to pluralize the relations of knowledge and authority present in citizen's opinions and attitudes, and directly impacts the performance of journalists who no longer have the prerogative of interpreting events.

However, within this context, how do journalists who explicitly write politically-opinionated blogs understand their own work? In this paper, we intend to analyze the professional identity of a well-known group of experienced Brazilian journalists who, at the same time, write independent blogs to express their political opinion and define themselves as "progressive" or "dirty". ${ }^{9}$

By "progressive" or "dirty" bloggers, we specifically refer to the journalists interviewed for this research: Altamiro Borges, Luis Nassif, Luiz Carlos Azenha, Paulo Henrique Amorim, Renato Rovai and Rodrigo Vianna $^{10}$, who were negatively referred to as "dirty" by Brazilian Social Democratic Party (PSDB) presidential candidate José Serra in 2010 because they had taken sides with the candidate of the Workers Party (PT), Dilma Rousseff, and other left-wing politicians. Well-respected on the Internet, these journalists organized their work collectively as a group in that same year, establishing a more active presence in the blogosphere, especially when sharing textual and audiovisual content and narratives about national politics contrary to those published by traditional media.

According to one interviewee, the term "dirty" came about when bloggers began to gather their ideas and articulate what would become the First Meeting of Progressive Bloggers during the 2010 presidential campaign"1: "

[...] Because we happily accepted the designation given by presidential candidate José Serra. When we launched the progressive bloggers movement, Serra gave a statement at the very night we held the meeting, ( ... ) that dirty bloggers were gathering in defense of the mensalão, among other things. It is a curious story because what happened is that Nassif, Paul Henry, Eduardo Guimarães, Altamiro Borges, Maria Frô, Conceição Lemes, Rodrigo Vianna and I, well, all ten bloggers met in a bar in São Paulo on Consolação street to set up the meeting; a bar called "Sujinho" (Dirtie) which used to be an old "brothel". The bar was known as such because it was located close to Augusta Street which was an area where many prostitutes used to work. And because this steakhouse would be open day and night, they would go up there for dinner and for a 
while that was how it was, but today it is known as "Sujinho". And now the name (of the bar) is actually Dirtie (Sujinho)"12.

The respondent stated that the then presidential candidate also referred to the bar in the same tone, in order to enlarge the negative sense of the adjective "dirty" to and used it to describe bloggers who supported rival candidates.

From this and from other interviews, it became clear that most of the bloggers who were interviewed had decided to "play" with the name and subvert the charge against them, using it to emphasize their blogs as a place where they can express opposition towards the dominant interpretations in political coverage throughout traditional media (or the "limpinhos"- "the cleanies"). Gradually, these "dirty" or "progressive" blog conquered their space in social networks and among social movement activists; forming new actors within the public scene ${ }^{13}$.

Here is a brief profile of the interviewed blogger-journalists:

Altamiro Borges, member of Communist Party of Brazil (PCdoB) has been writing his blog: Blog do Miro: uma trincheira na luta contra a ditadura midiática (Miro Blog: a trench in the war against media dictatorship (http://altamiroborges.blogspot.com.br/) since 2008. According to Borges, the blog effectively began to work in 2010.

Luis Nassif, more than 40 years of experience as a journalist, he is a well-known economic journalist and former employee for Folha de $\mathrm{S}$. Paulo, among other Brazilian newspapers. He is the author of Luis Nassif Online (http://www.advivo.com.br/luisnassif/), linked to Brasilianas.org and hosted on his company's website Agência Dinheiro Vivo (Advivo) (http://www.advivo.com.br/) His blog has been around since 2005, but according to the journalist himself, he was the first to introduce electronic journalism to the country with his company in 1988.

Luiz Carlos Azenha, experienced television reporter and former broadcast journalist of Manchete, SBT, and Globo, created the blog Viomundo (http://www.viomundo.com.br/) in 2002 when he was still a foreign correspondent in New York working for TV Globo ${ }^{14}$.

Another experienced journalist, Paulo Henrique Amorim, began his career in 1961 working for the Rio de Janeiro newspaper A Noite. Former Globo TV reporter and current Record TV anchorman, he is the author of the blog http://www.conversaafiada.com.br/ created in 2006. The blog is currently a directory which includes publishing content in multiple formats.

Renato Rovai is the editor of Revista Forum (http://revistaforum. com.br/) and the author of Blog do Rovai (http://revistaforum.com.br/ 
blogdorovai/). Since the early 2000s, he has kept "a mailing list called Side B used to distribute the magazine and other printed texts [...] that could not endure the length of time imposed by the print magazine market". According to the journalist, the blog was created to "practice journalism as a way to write an opinion piece, as well as to produce some stories that I think are more suitable for the Internet."

Rodrigo Vianna was a journalist for the newspaper Folha de S. Paulo, television reporter at TV Cultura and Globo TV, and currently works as a journalist for Record TV. He has been writing his blog O Escrevinhador (http://www.rodrigovianna.com.br/) since 2008. According to Vianna, the decision to start up the blog occurred after he left Globo TV in 2006. For the journalist, the blog "was a tool to intervene in the debate without being subjected to the constraints imposed by corporate journalism".

We will further discuss the theoretical and methodological choices for conducting the research and characterize the role of blogger journalists in more detail.

\section{THEORETICAL AND METHODOLOGICAL NOTES}

This paper aims at understanding how these bloggers define and practice journalism, and how they view their own role in the democratic context. From interviews conducted individually between the months of August 2012 and April 2013'5, definitions were mapped out and associated with journalism and the journalistic values they expressed; outlining the identity of a blogger journalist who advocates critical journalism, i.e., opinionated or explicit political positioning.

The questions focused on what journalism is, its definitions, what the main functions of political journalism are, the values that define journalistic activities and that are fundamental to its subculture. The questions also focus on what bloggers think about democracy and Brazilian politics among other issues that are relevant to the investigation concerning relationship between political culture and journalism subculture.

We also seek to identify the characteristics of these journalists' personal and professional trajectory by asking questions concerning their origin / place of birth, educational background, work experience, career, and other relevant aspects of process of producing online news.

In addition to the interviews, the research team followed the mentioned blogs during the weeks of $08 / 02 / 12$ to $08 / 08 / 12$ and $01 / 27 / 13$ to $02 / 02 / 13$, in order to map out the type of content which is 
posted, the highlights, the major themes, original blogger publications (such as reviews, news, columns, etc.) and / or republishing (other authors' texts often reproduced and commented on by bloggers), and reader comments.

Then a table of key settings and values was set up to compare journalism and politics, looking at their perceptions of democracy. The results of our qualitative analysis will be prioritized according to the field of journalism. Although politics has always been present in these journalists' careers and in the background of our observations, it is from a journalism point of view that we seek to understand what these bloggers do. Obviously, this methodological choice is just a snippet of the numerous possible forms of analysis available and does not exhaust the subject.

It is also necessary to mention some theoretically relevant aspects. Firstly, it is our belief that journalists form an interpretative community that shares specific journalistic values (Zelizer, 1993). These values represent the broader elements of dominant culture, as Williams (1979) pointed out, made up of a complex system of customs, traditions and habits, or as a symbolic system that occupies the center of our lives (Hall, 1997).

They also refer, in particular, to the dominant political culture of a society perceived from a cultural perspective as a set of ideas, habits, traditions, feelings and beliefs that might be constantly renewed, rebuilt and/or refuelled back into everyday life. This implies the recognition of an active element in building and sharing culture over politics, that is, from the tensions and contradictions of political life (Guazina, 2011).

Secondly, in the case of journalists in general, shared values refer to their own professional subculture, characterized mainly by an emphasis of distrust towards politicians (one of the dominant values of Brazilian political culture) and based on the task of monitoring and investigating hidden government acts (ibid., 2011).

It is worth mentioning that the journalistic subculture involves belief in values related to objectivity, professionalism, immediacy, the power of supervision and surveillance. Journalists share a specific ethos; a professional identity of their own way of seeing the world, and at the same time, reporting the facts (Traquina, 2001).

Such considerations might help us to understand the work of "progressive" or "dirty" blogger journalists, since most of them share (or shared) of successful experience of journalism while working for major media companies and, from a certain point, expanded their acquired 
skills as professionals to work in a more personal and direct way on political debates on the Internet.

Interestingly, while presenting a more editorial point of view on their blogs and opinions, these journalists rely on their journalism background and create a different way of perceiving the profession; not necessarily linked to the standard of objectivity and neutrality which media claims as unique factors of credibility.

We will further detail some of the main features of the trajectory and the professional experience of bloggers, looking at how they define and practice journalism in their blogs.

\section{PROFESSIONAL TRAJECTORIES OF "PROGRESSIVE" OR "DIRTY" BLOGGERS}

From a personal and professional trajectories perspective, all of the bloggers surveyed for this paper are men over the age of 40 with extensive experience in the field. Most of them are widely recognized outside their Internet activities, especially in national newspapers and television stations. This is different from the profile of Brazilian female journalists in the field (Bergamo, Mick and Lima, 2013), who are around 30 years of age, graduated from private colleges with little professional experience. With the exception of Altamiro Borges, whose professional career is based exclusively in alternative media, the other bloggers are characterized by having worked (or are still working) in major media.

Moreover, despite different backgrounds and education (all have university level in various Humanities courses), blogger journalists live in the state of São Paulo and keep themselves up-to-date with political coverage published in the national media and on different blogs, websites and social media connected to a vast network of independent readers and/or linked to social movements, political parties and various society organizations.

Most "progressive" bloggers started their blogging experience in the early 2000s, publishing editorials, opinionated texts, or just simple texts on daily political events. Paulo Henrique Amorim, for example, wrote some of the first publications on portals like Zaz and Terra in the late 90s. As one of the interviewees states (E5), "before I even had a blog, I was blogging". Political participation from the general public is one of the characteristics of this group of bloggers, regardless of the media in which they express their opinions.

The information contained in the interviews shows that the 
Internet expanded the once restricted political participation to a national level, since there was no way of including daily professional practice with political beliefs and/or individual ideologies, especially those linked to the mainstream media. Blogs were a way of freely balancing journalism with the perception of society and politics.

It is also possible to say that "progressive" bloggers do not always adopt exactly the same positions on all political issues, but they make an effort to support each other as a group, republishing texts or commenting on each others' publications, as well as articulating themselves at events, such as the Bloggers National Meeting, which had its third edition in Salvador in May of 2012. Not only did the event bring together bloggers, but also a diverse audience of journalists, left-wing political party activists, social movement activists, as well as participants and organizations involved in the debate on the democratization of Brazilian communication. ${ }^{16}$

Although specific inquiries about how "progressive" or "dirty" blogs are financed were not made, it is evident from the published texts that the bloggers mentioned in this article do not always share the same opinion about the forms of sponsorship and/or fund-raising used in financing their blogs. Azenha states, for instance, that his blog does not accept sponsorship from organs linked to the government ${ }^{17}$, yet Paulo Henrique Amorim's blog advertise public and private bank banners.

At any rate, the discussion over blog financing is controversial and occasionally appears in texts and interviews, once researching, editing, prioritizing and/or simply writing articles, commenting on texts and responding Internet users requires journalists time and dedication, besides implying costs and structures.

Moreover, this discussion refers to the actual debate on the capacity for different political ideologies in media, particularly minority or independent ones, to survive the concentration of market communications in Brazil without the need for public funds, and to respond to lawsuits carried out by large media companies or other groups/individuals mentioned in the texts. ${ }^{18}$

Considering the production process perspective, every blogger has their blog linked to different work structures. Some have their own businesses and rely on teams and physical spaces (newsroom), others work in conjunction with the readers themselves or permanent and future collaboration with other bloggers.

From the interviews and texts published in their own blogs, it is evident that the journalists' "dirty blogs" mentioned in this text did not 
start at the same time nor did they necessarily share the same goals at first. The creation of blogs happened, among other factors, from the convergence between professional and personal life of each journalist and the popularization of the Internet in the country since the 2000s.

The strengthening of blogging and its recognition by Internet readers occurred with the intensification of public debates on politics, especially with the polarization of opinions after the political crisis of 2005 during Lula's government and the presidential elections of 2006 and 2010. After the 2010 election campaign, blogger journalists have achieved a more accentuated profile of collaboration, sharing the strengthening trend of political participation through online/offline social networks.

After analyzing the interviews, the journalists are convinced that it is necessary to make a contrasting point of view to that of traditional (or dominant) commercial media; they have a personal and professional duty to intervene in the national political agenda.

Most blogger journalists claim that they write opinionated articles on the Internet, and their work is not restricted to just delivering the facts, but mainly to writing columns (republished) or sharing thirdparty content (including texts from commercial media) duly termed as "personalized" (for example, analyzed and commented on by a journalist blogger). One of the journalists interviewed (E5) believes that his blog is "another space to write columns, it is journalistic, but it is a column in nature. It is an editorial space; it is not a space for reporting."

In general, "progressive" or "dirty" bloggers publicly identify themselves as journalists with a left-wing or progressive political viewpoint (as mentioned by Mastrini, 2012), even though they are not always directly linked to political parties or governments ${ }^{19}$. According to another interviewee (E6), "blogs can be critical and take part on a debate, but always without sacrificing their independence, criticizing whenever possible, from a left-wing viewpoint."

According to the interviews, political opinion is understood in the context of a working Brazilian democracy. One interviewee (E4) exemplifies this view by defining his blog as "offering the reader a different point of view from that one expressed in the powerful CPP (Coup Press Party)." In the words of another interviewee (E6), "opinionated journalism in blogs more directly influences debates, contrasting with corporate media, which we bloggers call "old media". Blogger journalists mentioned the diversity of interpretations and the vast amount of voices and opinions as fundamental requirements for a fully functioning 
democracy, coming close to the perception of radical democracy defined by Miguel (2007), in contrast to the discourses of traditional dominant media.

Most of the journalists interviewed pointed out the lack of space in traditional media towards different approaches on politics matter and the "casting" of the commercial production process of news as reasons to think about producing more freedom in their personal blogs. According to one of the bloggers interviewed, nowadays there is less diversity in editorial content and more economic power in the experience of large media companies. ${ }^{20}$

\section{WHAT IS JOURNALISM FOR "PROGRESSIVE" OR “DIRTY” BLOGGERS}

When asked to define journalism, the interviewees converged around definitions that comprehended the defense of public interest, the citizens' awareness through information, the promotion of contradictions and the surveillance of authorities, including the media corporations. They all heavily criticized the commercial journalism in practice today and the concentration of power that large media groups hold which limits the diversity of opinions expressed in political debates. On the other hand, they did stress that the profession as fundamental do democracy-building and the experience of citizenship through analyzing, clarifying, and informing journalism work means.

For example, one of the interviewees (E6) says "journalism is a profession that, if well performed, allows the public reader/viewer to interact with the world more critically, with more information. This is ideal. In practice, journalism is a tool to power dispute. Ideas or values are imposed through it - which may serve to different projects within society".

According to another interviewee (E4), "journalism is informing and enabling the reader/viewer to make choices within a democratic society". Previously interviewed E3 says that journalism can be summed up "in three words: the public interest." For him, however, the economic interests and tendencies large media corporations have for turning news into entertainment are changing the nature of journalism: "Journalism has become a show, and has less relevance in the discussion of really important Brazilian issues, its political agenda, and the public interest; it ended up getting further and further away from the work that we do".

According to another interviewee (E2), ideal journalism is the one that can "translate the discourse of various economic and social 
agents in the most free and educational way possible." About political journalism, he says, "it has always been a means of politics dissemination, whether it is a political supporter or social and economic organizations. A political analyst should know how to contextualize the daily facts, and the reporter should know how to get the facts. Currently it is being used as a weapon for political parties."

However, regardless of the type, the interviewee (E2) emphasizes that good journalism "respects the facts. It provides the reader with all elements including the ones to disagree with final decisions, promotes contradictory thinking and gives the right to answer."

With regards to how journalism works within democracy, he points out the defense of social and individual rights and the control of other powers, including the media itself. As for blogger journalist $E 5$, the main function is to ensure the practice of expressing different and contradictory opinions in a free media environment. According to another interviewee (E4), the main function of journalism is to impartially inform and criticize the powerful. For interviewee E1, the main functions of journalism are "to contribute to reducing social poverty and overcome any type of oppression, including prejudices, and to investigate the main bottlenecks of society, avoiding scandal and tabloid journalism".

For interviewee E6, the main function of journalism "should be to create a well-informed public capable of discerning among the various proposals or projects under debate'. In practice, it does not work like that. Journalism is in the hands of families or corporations, who use it as a means to defend projects, but they cover it up under a false pretense of "objectivity" and "neutrality."

No blogger journalist questions the value of neutrality in journalism, but interviewees E5 and E6. According to the latter, "there is no neutral journalism; journalists are not neutral, citizens are not neutral. What you may have is an effort to - assuming we all have ideologies and views - seek the greatest possible objectivity. Having an opinion and a view does not mean twisting or concealing the factual truth. This must always be respected." For interviewee E4, one way to inform is to offer a dissenting opinion.

The most mentioned values associated to journalism by blogger journalists were the commitment to the facts, promotion and defense of democracy, plurality of information assurance through diversity of opinions, and permanent monitoring of powers (not only the government but also media and private companies), and honesty. ${ }^{21}$ 


\section{TEMPORARY CONSIDERATIONS}

As mentioned before, this is a snippet on the relationship between political culture and professional subculture observed through the work of blogger journalists. Therefore, we consider our observations as notes and our conclusions as contributions to the study of political journalism on the Internet.

Based on the interviews, we observed that blogger journalists define journalism the same way their colleagues who work in traditional commercial media do, that is, they define values generally seen as constituting the profession (such as the public interest, clarification, surveillance power).

However, blogger journalists understand these and other terms associated with variables such as the need to expand political pluralism in media, criticism of "old media" journalism (as defined by interviewee E6) and the impossibility of exercising political journalism giving up on political participation ${ }^{22}$.

From the analysis of interviews and observations of "dirty" blogs, it can be said that the respondents consider their blogs journalistic activity, a place to express the diversity of opinion within traditional media, and that their main function as journalists is to watch over all political powers, including the media.

From this perspective, we understand that blogger journalists articulate interpretations, often alternative ones. Their profession notion and the ethos also consist of variables from the political field, allowing them to recognize themselves as active subjects in the construction of politics as professionals and citizens (Guazina, 2011). These journalists take on the tensions and contradictions of political debate and of their own professional practice. In the words of one interviewee: "good journalism is the one which assumes itself as critical, without distorting the facts; without hiding the facts."

Finally, two other interesting factors observed about "progressive" and "dirty" bloggers: The first is that the Internet seems to have represented the possibility of expressing personal political views (and even political activism) in a moment when the professional experience in other means of media has been exhausted, yet at the same time not necessarily changed the understanding of journalism. Secondly, for having assumed the names "progressive" and "dirty", and setting up meetings with other blogger journalists, the journalists interviewed here have strengthened new networks of political participation, inspiring 
posts from other blogs, websites and social media; therefore, influencing the public agenda.

In such sense, they continue to be a sort of "elite" group of blog journalists writing about politics, especially about the left-wing. They serve as guides to the interpretation of political events, and construct online narratives that come up minute by minute, in the battle for an audience.

\section{NOTES}

1 This paper presents partial results from the project Cultura Política e Subcultura Jornalística em tempos de Internet elaborated in 20122013 along with scholarship recipients Luana Melody Brasil and Angela Oliveira from the School of Communication at the Universidade de Brasilia. The main objective was to compare the values related to politics and journalism expressed in personal narratives and in blogs written by journalists in "progressive" media and traditional and "commercial" media (linked to major news portals). Thanks to the staff for data collection and interviews, as well as to the undergraduate student Guilherme Alves Pinheiro for his collaboration. Part of the argument concerning the relationship between political culture and journalism was developed in Guazina (2011).

2 Obviously, online political dispute is not limited to what is expressed in journalism sites and blogs (or those that present themselves as such to their readers). As seen in recent popular demonstrations in Brazil, it encompasses every kind of expression of opinion connected to social movements, organizations, and individuals on different social networks that organize themselves autonomously. In this paper, however, we will stick to journalism-related implications.

3 With regard to new forms of political participation and social organization in Brazil, including election time, cf. Lima, 2006; Chimento, 2009; Teixeira, 2010; Sampaio, Azevedo and Almada, 2011; Souza and Penteado, 2013, Araújo and Santos, 2013.

4 Most interfaces and /or "friendly" devices used for the publication of online texts, videos and audio have appeared since the 2000s. Social networks like YouTube and Facebook, which currently constitute popular loci of political manifestation, initiated in 2005 and 2004, respectively (Schudson, 2009).

5 Especially, journalist Ricardo Noblat's blog (http://oglobo.globo.com/ pais/noblat/), as Adghirni and Pereira stated (2006).

6 We understand journalistic blogs as defined by Adghirni and Pereira (2006). 
$7 \quad$ About blog typology and characteristics, cf. Recuero (2003).

8 On social movements and internet, cf. Castells (2012) and Malini and Antoun (2013).

9 Though admittedly controversial, the term "progressive" is mentioned here not only because it is cited by bloggers in interviews and in their blogs, but also because they associate it to the term elements/ideas similar to those defined by Mastrini (2012), referring to the agenda of leftwing political communication governments in Latin America: especially the appreciation of the State as a political actor capable of ensuring the balance of interests in society, the defense of the right to communication, and the critical concentration of the media, among others.

10 For this study, we chose the most well-known bloggers on the net. Leandro Fortes, identified by other blogger journalists as "progressive" for his criticism of the traditional media, was interviewed for our research. However, he has not been included in this article because he was not mentioned as part of the initial group of "dirty" bloggers. Luis Nassif does not refer to himself as a "dirty" blogger, yet he was included because he has been cited as having participated in the articulation of the First Meeting of Progressive Bloggers. According to the site http://www. alexa.com/, Luis Nassif's blog is the most visited at 502nd place in the national rankings. Paulo Henrique Amorim is the second most visited at 665th. Then Luiz Carlos Azenha's blog at 1,277th, Altamiro Borges at 3,243rd, Renato Rovai's blog at 4,407th, and Rodrigo Vianna at 5,523rd (last accessed on 04/22/2013). In addition to their blogs, bloggers also maintain Twitter accounts, Facebook profiles and make use of links to other sites.

11 The event took place in August of that year and marked the beginning of the unification of a wide network of activist bloggers, in general, composed of different movements or left-wing groups in the country.

12 Maria Frô is the name used by Conceição Oliveira in her blog (http:// mariafro.com/), which sits at 14,267th in the national rankings (http:// www.alexa.com/siteinfo/mariafro.com). In Portuguese, the word "sujo" means dirty; and the bar name ("Sujinho") refers to a historical and traditional bar for the working class in downtown São Paulo.

13 Souza and Penteado (2013) state that "progressive" bloggers could, in episodes such as the paper ball thrown at José Serra's (presidential candidate) head in 2010, contest coverage of traditional media; especially the TV station such as Globo that constitutes a network of counter-information and broaden the debate on electoral coverage and the direction of the political process. In Portuguese, the word "limpinho" refers to something (or someone) clean.

14 Both Luiz Carlos Azenha and Rodrigo Vianna worked for Globo TV and left the station after controversial episodes related to differences in relation to the company's news coverage on the 2006 presidential elections (cf. LIMA, 2007). In an interview with the young researcher Luana Brasil, 
Azenha states that he asked to terminate his contract prematurely and his departure from Globo TV was a difficult time in his career. Recently, Azenha has been ordered to pay compensation to Globo TV for content posted on his blog and he almost stopped updating it. A network collaboration (crowdfunding) was created to help pay the fine given by the courts and the journalist decided to keep the blog active after reader requests to keep it going. According to Azenha, Viomundo has 40,000 followers on Twitter and Facebook. See more details at http://www. viomundo.com.br/opiniao-do-blog/o-leitor-que-me-fez-mudar-de-ideia. html

15 The interviews were conducted by email, hangout (Google Video) and by making questions available online through survey tool SurveyMonkey (http://pt.surveymonkey.com/). There was a greater interaction between interviewer and interviewee when using Google hangout.

16 CF. http://www.rodrigovianna.com.br/radar-da-midia/blogueiros-sujosde-uma-imprensa-limpa-nada-alem-da-constituicao.html (last accessed 04/15/2012).

17 http://www.viomundo.com.br/opiniao-do-blog/o-leitor-que-me-fezmudar-de-ideia.html

18 See http://www.viomundo.com.br/opiniao-do-blog/o-leitor-que-mefez-mudar-de-ideia.html (last accessed 04/15/2013) and http:// www.conversaafiada.com.br/tv-afiada/2013/04/15/bernardo-naomete-medo-a-globo-e-mete-nos-blogueiros-sujos/ (last accessed 04/15/2013). Besides Azenha, Rodrigo Vianna was also ordered to pay compensation to Globo TV for content published on the blog. Cf http:// www.rodrigovianna.com.br/palavra-minha/resposta-ao-uol-a-represaliae-da-globo.html

19 The exception being Altamiro Borges who is represented as a journalist, as president of the Baron Itararé Center for Alternative Media Studies, PCdoB supporter, and author of the book "A ditadura da mídia."

20 As pointed out by several authors, the lack of diversity / plurality in traditional media is one of the reasons for blogs being used as a form of expression / political action in various countries. See Canavilhas (2004).

21 In comparative terms, the research results showed that both blogger journalists called "progressive" or dirty" and blogger journalists linked to traditional media portals understand Brazilian democracy in general; that it is going through a maturing process and mistrust in politics as a relevant feature of Brazilian political culture and subculture professional.

22 Miguel (2007) points out, and rightly so, the expansion of pluralism as a major challenge for the improvement of Brazilian democracy. 


\section{REFERENCES}

ADGHIRNI, Z. and PEREIRA, F. Perfil profissional no ciberjornalismo: o blog como espaço de autoria e identidade na web. Article presented at the $7^{\text {th }}$ National Meeting of Researchers in Journalism - SBPJOR, 2006. Available at: http://sbpjor.kamotini.kinghost.net/sbpjor/admjor/arquivos/coord3_zelia_ adghirni_e_fabio_pereira.pdf. Accessed on: 04/21/2013.

ADGHIRNI, Z. and PEREIRA, F. O estudo do jornalismo em tempos de mudanças estruturais. Revista Intexto, PPGCOM-Federal University of Rio Grande do Sul, vol. 1, 2011 . Available at: <http://seer.ufrgs.br/intexto/article/view/19208>. Accessed on: 04/21/2013.

ALDÉ, A. and CHAGAS, V. Blog de política e identidade jornalística (transformações na autoridade cognitiva e na relação entre jornal e leitor). Work presented at the $5^{\text {th }}$ Meeting of Research Centers at the $28^{\text {th }}$ Brazilian Congress of Communication Sciences - Intercom, Rio de Janeiro, September 5-9, 2005. Available at: <http://www.portcom.intercom.org.br/pdfs/610395 24264263187770628453405402334909 .pdf.> Accessed on: 04/15/2013.

ALDÉ, A., ESCOBAR, J. and CHAGAS, V. A fibre dos blogs de política. FAMECOS, Porto Alegre, n. 33, august, 2007, p. 29-40. Available at: <http://www. revistas.univerciencia.org/index.php/famecos/article/viewFile/3257/3084> Accessed on: 11/29/2013.

ARAÚJO, R. de P. e SANTOS, M. B. Mobilização social e sociedade civil em São Paulo: construção do índice de participação política. Article presented at the Work Group for Communication and Civil Society at the $5^{\text {th }}$ Compolitica Congress, Curitiba/PR, May 8-10, 2013.

BERGAMO, A., MICK, J. e LIMA, S. Quem é o jornalista brasileiro? Perfil da profissão no país. Available at: <http://perfildojornalista.ufsc.br/> Accessed on $11 / 26 / 203$.

CANAVILHAS, J. Webjornalismo. Considerações gerais sobre jornalismo na web. In FIDALGO, A. e SERRA, P. Jornalismo on line. Beira Interior University, Covilhã, 2003. Available at: <http://www.livroslabcom.ubi.pt/book/79> Accessed on 11/26/2013.

CANAVILHAS, J. Blogs políticos em Portugal: 0 dispositivo criou novos actores? 2004. Available at: <http://www.bocc.ubi.pt/_esp/autor. php?codautor $=602>$ Accessed on 11/29/2013.

CASTELLS, M. Redes de Indignación y Esperanza. Madrid, Alianza Editorial, 2012.

CHIMENTO, M. O palanque virtual: relações entre os blogs de política e a imprensa na eleição de 2008. Work presented at the "Communication and Politics" Work Group at the $18^{\text {th }}$ Compos Meeting, PUC-Minas Gerais, Belo Horizonte, June 2009.

GUAZINA, L. Jornalismo em busca da credibilidade: A cobertura adversária do Jornal Nacional no Escândalo do Mensalão. PhD thesis, University of Brasília, 2011.

HALL, S. The centrality of culture: Notes on the cultural revolutions of our 
time. Education and Reality, Porto Alegre, \#22 (2), pg.15-45, 1997.

LIMA, V. A. A mídia nas eleições de 2006. São Paulo, Fundação Perseu Abramo Publishing House, 2007.

MALINI, F. e ANTOUN, H. A internet e a rua: ciberativismo e mobilização nas redes sociais. Porto Alegre, Sulina Publishing House, 2013.

MASTRINI, G. Governos progressistas e meios de comunicação na América Latina. In. CHRISTOFOLETTI, R. e LIMA, S. (ORG.). Reportagem, Pesquisa e Investigação Florianópolis, Insular/UFSC, 2012, pg. 37-49.

MIGUEL, L. F. O possível a quém do necessário: transformando a ação política da mídia no Brasil. In LIMA, V. A. Media in the 2006 elections. São Paulo, Fundação Perseu Abramo Publishing House, 2007.

RECUERO, R. "Warblogs: os blogs, a guerra no Iraque e o Jornalismo Online". Work presented at the Information and Communications Technology Center, $26^{\text {th }}$ Annual Congress on Communication Science, Belo Horizonte / Minas Gerais, September 2003. Available at: <http://www.bocc.ubi.pt/pag/ recuero-raquel-war-blogs.pdf> Accessed on: 04/21/2013.

SAMPAIO, R., AZEVEDO, D., and ALMADA, M. P. Esfera civil e eleições 2010: Uma análise de iniciativas online para maior controle civil. Article presented at "Communication and Politics" Work Group for the $4^{\text {th }}$ Compolítica Meeting at the University of the State of Rio de Janeiro, Rio de Janeiro, April 13-15, 2011. Available at <http://www.compolitica.org/home/wp-content/ uploads/201 1/03/Rafael-Sampaio-et-alii.pdf> Accessed on 11/29/2013.

SOUZA, P. R. e PENTEADO, C. L. Blogs e contra-informação política: redescobrindo uma forma de luta simbólica na blogosfera. Article presented at the Political Journalism Work Group for the $5^{\text {th }}$ Compolitica Congress, Curitiba/PR, May 8-10, 2013.

SCHUDSON, M. Ten years backwards and forwards. Journalism. Sage Publications. Vol. 10 (3): 368-370, 2009. Available at: <http://jou.sagepub. com/content/10/3/368. citation>. Accessed on: 11/26/2011.

TEIXEIRA, T. Web 2.0/3.0, políticos e cidadãos: riscos e oportunidades para a democracia. Article presented at the $7^{\text {th }}$ Meeting of the Brazilian Association of Political Science - ABCP, Recife, August $4^{\text {th }}$ to $7^{\text {th }}, 2010$.

TRAQUINA, N. O Estudo do Jornalismo no século XX. São Leopoldo, Unisinos, 2001.

WILLIAMS, R. Marxismo e Literatura. Rio de Janeiro, Zahar, 1979.

ZELIZER, B. Journalists as Interpretative Communities. Critical Studies in Mass Communication, vol. 10, \#3, September, pg. 219-237, 1993. 


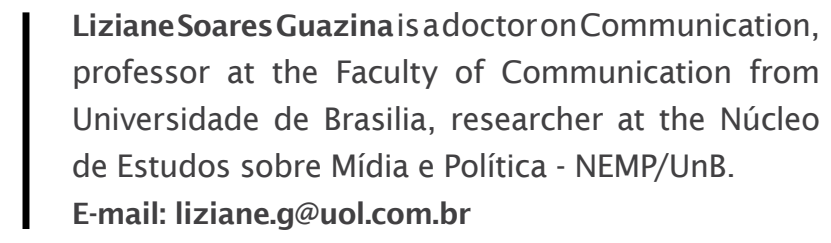

RECEIVED ON: 13/08/2013 | APPROVED ON: 23/10/2013 
CRITICAL JOURNALISM 